\title{
EZRA POUND, «LOPISTA»
}

\section{Gayle Rogers (University of Pittsburg)}

«This much is apparent: Spanish literature declined with Spanish world power; people came to Madrid to look at the "Fénix de los ingenios," Lope de Vega y Carpio, but since his time no man has gone to Spain to pay intellectual homage. [...] Was Madrid ever a metropolis; was Spain ever a centre of thought, ever, that is, after the fall of Moorish dominion and the devastation of Cordova?»

Ezra Pound [1991:16 $]^{1}$

Cita Recomendada: Gayle Rogers, "Ezra Pound, "lopista”», Anuario Lope de Vega. Texto, literatura, cultura, XXII (2016), pp. 217-237.

DOI: < $\underline{\text { http://dx.doi.org/10.5565/rev/anuariolopedevega.145> }}$

Fecha de recepción: 22 de junio de 2015 / Fecha de aceptación: 17 de septiembre de 2015

\section{RESUMEN}

Este artículo pone de manifiesto el temprano y profundo interés de Ezra Pound en la obra de Lope de Vega. El joven Pound estudió a Lope en la universidad e inició una tesis doctoral sobre la figura del gracioso, bajo la dirección del afamado lopista Hugo Rennert. Aunque Pound abandonó su proyecto de tesis, tradujo pequeños fragmentos de las obras de Lope de Vega (incluido un poema de Los pastores de Belén) y, lo que es más importante, utilizó escenas y citas de Las almenas de Toro para estructurar las primeras partes de lo que terminaría convirtiéndose en The Cantos. Me centro en los diversos modos en que esas traducciones y citas ayudaron a Pound a definir los temas fundamentales de sus llamados «Ur-Cantos» - los tres primeros poemas de los Cantos que publicó en 1917, antes de revisarlos a conciencia y republicarlos en su primer libro, A Draft of. XVI Cantos (1925)_. Para entender este proceso, analizo el capítulo sobre Lope de Vega en su ensayo The Spirit of Romance (1910). Propongo que, en última instancia, Pound rechaza el estilo barroco de Lope de Vega y escenifica ese rechazo a lo largo de Los Cantos, donde descarta lo barroco como excesivamente «ornamental» y poco perdurable a lo largo de la evolución literaria; de ahí que no fuera ese el estilo que Pound adoptará en el desarrollo de The Cantos durante el resto de su vida.

Palabras Clave: Lope de Vega, Ezra Pound, Hugo Rennert, traducción, Los pastores de Belén, Las almenas de Toro, Los Cantos, El espíritu del romance, Barroco.

\section{Abstract}

This article reveals Ezra Pound's deep, early engagements with the works of Lope de Vega. A young Pound studied Lope de Vega in graduate school and began a doctoral thesis on the gracioso figure in

1. All spelling and orthography in Pound's writings, including his mistakes in Spanish (e.g. "Cordova»), are transcribed as in the originals. 
his plays, under the direction of famed lopista Hugo Rennert. But Pound abandoned his dissertation and, instead, translated small parts of Lope de Vega's works (including a poem from Los pastores de Belén) and, more important, used scenes and quotations from Las almenas de Toro to structure the early parts of what would become The Cantos. My focus is on the ways in which these translations and quotations helped Pound discover his governing themes for what are called his «Ur-Cantos» the first three poems of his Cantos that he published in 1917, before he would revise them heavily and republish them in his first book, A Draft of XVI. Cantos (1925). To understand this, I analyze his chapter on Lope de Vega in his textbook of translations and scholarly commentaries, The Spirit of Romance (1910). Pound ultimately rejects Lope de Vega's Baroque style, I argue, and stages his rejection across The Cantos, where he dismisses the Baroque as too heavily «ornamental» and not sufficiently suspended across literary time, and thus not the style he will use in developing The Cantos across the remainder of his life.

Keywords: Lope de Vega, Ezra Pound, Hugo Rennert, translation, Los pastores de Belén, Las almenas de Toro, The Cantos, The Spirit of Romance, Baroque. 
$\mathrm{B}^{\mathrm{s}}$ efore he was an avant-garde poet, a founder of movements, a modernist kingmaker, an international provocateur, or a political ideologue, Ezra Pound wanted to be a lopista. But in 1906, when he abandoned his thesis on the gracioso, or buffoon figure, in the plays of Lope de Vega, he effectively abandoned a potential career as a professional scholar of Spanish and Romance-language literatures. The typical reading of Pound's career assumes that the poet's experiences in graduate seminars on medieval Spanish literature, in archives in Madrid while on a research fellowship, and among the ruins of the legendary Spanish hero El Cid's castle in Burgos mattered to his later work only insofar as they provided fragments of material that he recycled in the Cantos. Such a reading yields limited fruits: by the time that Pound published A Draft of XVI. Cantos in 1925, Spain and its literature had all but receded form his purview; Browning, Greek mythology, Chinese dynasties, Renaissance Italy, and many other figures and sites instead came to the foreground.

Moreover, to recover Pound's sustained grappling with Spain's cultural past is to do more than flesh out a footnote for the Cantos. Pound might have quit the academy, but he continued practicing the skills he learned there; indeed, he transformed them into the «New Method of Scholarship» (Luminous Detail) that he elaborated in 1911. He did so with the texts that he discovered in his training, weaving them into his poetry, translation, criticism, scholarship, and cultural politics. His Spanish engagements, that is, were the foundation for what was a major intellectual project of Pound's — often on a par with, and entwined with his poetic career — all the way through the first draft of the epic that consumed his adulthood: the "Three Cantos of a Poem of Some Length» (1917), collectively known as the «Ur-Cantos». This essay reads the "Ur-Cantos» as both an endpoint and a beginning, a fulcrum between two stages of Pound's career. At the heart of the first stage, which lasted roughly from 1905 until shortly after 1917, was an audacious multi-pronged effort to dismantle the practices of Germanic philology, to revise the shape of comparative literary studies for the new century, to renovate the reigning modes of translation, and ultimately, to lay the groundwork for rewriting literary history poetically, all while the poet was still in his mid-twenties. 
The primary scene for these projects was Pound's groundbreaking study The Spirit of Romance (1910). Here, Pound attempts to leave behind his would-be career as a lopista and to distance himself from his mentor Hugo Rennert, all while devoting significant attention to Lope de Vega and to the Poema del Cid. He thinks comparatively about Lope de Vega's legacy in world literary history, but also aims to dismiss him —or to praise him—, and Rennert by proxy, only partially. The gap between the two stages of Pound's career that I am adumbrating, that is, can be traced through his treatments of Lope de Vega in his translations, criticism, and poetry, and indeed through his revisions, excisions, and silences on the Spaniard during the latter stage of his still-nascent career. Through Lope de Vega and beyond him, Spain proves a problematic historical case for Pound in his thinking about cultural coherence and change - elaborated later in his thoughts on kulchur and paideu$m a$. Against his general desire to separate "world power" and literary greatness when readings past empires, he comes to see the two as converging in the case of Spain, as he explains in a controversial article on Spanish literature that he published in Spain in 1921. His claim that Spain's empire and literature declined together, that is, seems at odds with his conviction that literature escapes its spatio-temporal constraints and «STAYS news» [2010:29]. By the time of the Cantos, his former object of study Lope de Vega provides little more than a series of corpses through which Pound critiques the Baroque and its use of ornament. Lope de Vega and his works, instead, compose fragments of a giant, transhistorical collage that variously embraces and repudiates the playwright's style and subjects, all in service of Pound's own emerging poetics.

\section{Pound, the Failed Hispanist}

As Pound later recalled, he entered college «at 15 with intention of studying comparative values in literature (poetry) and began doing so unbeknown to the faculty [....] I began an examination of comparative European literature in or about 1901; with the definite intention of finding out what had been written, and how» [1963:15]. In his undergraduate studies at Hamilton College, where he settled after his precocious time at the University of Pennsylvania, Pound pursued a program of comparative literary study in which he enthusiastically put himself «at risk of being perceived 
as arrogantly cross-grained», as A. David Moody writes [2007:15]. He studied Spanish alongside several Romance languages with the scholar of Provençal William P. Shepard, whose imprint remains visible in The Spirit of Romance. Pound joked about his work in «Dago lit», using the derogatory term for Spaniards and Italians at the time (qtd. in Carpenter 1988:55). He also read modern German, French, and Spanish (including Benito Pérez Galdós's Doña Perfecta, to which he would return several times in his critical essays) alongside troubadour poetry, Dante, Anglo-Saxon poetry, the Bible, and Chaucer. Coupling this work, from the start, with his translational poetics, Pound also published his first translation, a bilingual alba or dawn-poem, in Hamilton's literary magazine. When he arrived at the University of Pennsylvania for his graduate studies in 1905, the budding scholar immersed himself more fully in late medieval and early modern Romance literatures —especially Spanish- by taking six of his seven courses with Hugo Rennert. Rennert, arguably the world's leading authority on Lope de Vega at the time, had just published his landmark The Life of Lope de Vega in 1904; he would become a member of both Archer Milton Huntington's Hispanic Society in the US and the Royal Order of Isabella the Catholic in Spain. Under Rennert's tutelage and influence, but with strongly international and transhistorical sensibilities, Pound took his first steps toward becoming a scholar of Spanish letters by starting his thesis on Lope de Vega.

Rennert helped secure Pound a Harrison Foundation Fellowship to continue his work in Madrid. In May 1906, Pound arrived in Spain with letters that allowed him access to manuscripts in the Biblioteca Nacional de España. (A librarian in Madrid asked him why he was studying Lope de Vega when Rennert had already written all that could be said about him). He worked also in the archives of the Royal Library of Escorial, a monastery just north of the city. Padre José María de Elizondo, who appears memorably in Canto LXXXI, helped Pound access a Guido Cavalcanti manuscript, while the American consul in Madrid enabled Pound to view an unpublished manuscript of Lope de Vega's in the royal palace's archives. In addition to other scholars and translators, Pound also met the playwright José Echegaray, who had won the Nobel Prize for Literature in 1904.

While in Madrid, Pound happened to be in the crowd at the wedding of Alfonso XIII to Victoria Eugenie of Battenburg, granddaughter of Queen Victoria. This wedding was supposed to heal some longstanding rifts in Anglo-Spanish relations, but all hope was lost when a Catalan anarchist attacked the wedding party with 
a grenade. Pound quickly left Madrid to tour Spain; he claims that he boarded a train just as the authorities were rounding up anarchists and foreigners after the assassination attempt. In Córdoba, which was «most remote from civilization», he left his guide and was pelted with vegetables for his odd dress and behavior (see Canto LXXXI). Most important, he traveled to Burgos, the old capital of Castile and the historical home of El Cid. Drawing on these experiences, he published his first three literary essays as a set in Book News Monthly (Philadelphia) in the fall of 1906. Repeating age-old Orientalist figurations as he imagines Spain's past through its present environs, Pound asserts that the "Spain of to-day» is an «inexplicable mixture of hell and paradise which no outlander can understand» [1906a:91]. He believes, too, in an exotic and romantic vision, that the «dream Spain» of the country's «old song-glory» still existed in certain parts, without the «taint» of the «appearance of modernity» [1906a:91]. When he arrives in «the Burgos of Myo Cid Campeador», Pound finds few signs of the Cid there, save the pillars of his ancestral home (Solar). Both the Cid and Lope de Vega - and these tropes of Hispanicity- would inform his future criticism and poetry in multiple ways [1906a:92].

Even as he claimed to "have my thesis so I can roll it out in one month's home work», Pound quickly drifted from his work on Lope de Vega, as this trip indicates [2010:91]. He was drawn instead to the Prado Museum, for instance, where he researched Velázquez. When he returned to the US, he would begin to translate Lope de Vega's comedy El desprecio agradecido (The Grateful Reject, 1633), but he never finished it, declaring instead that he did not want to bore contemporary readers with it. ${ }^{2}$ He included his translation of Lope de Vega's "A Song of the Virgin Mother» (from Los Pastores de Belén, 1614) in his Exultations (1909), in Christmas calendars for his father's business, and, later, in Mark Van Doren's capacious Anthology of World Poetry (1928). ${ }^{3}$ He rendered the lines as follows:

«A Song of the Virgin Mother»

As ye go through these palm-trees

O holy angel;

2. See Pound [1916:122-32]. Pound also tried his hand at translating a few Spanish romances, or ballads. Pound likely influenced William Carlos Williams's decision to attempt a translation of Lope de Vega's El Nuevo Mundo descubierto por Colón.

3. In Exultations, Pound reprints, in the original Spanish, the final six lines that he translates. 
Sith sleepeth my child here

Still ye the branches.

O Bethlehem palm-trees

That move to the anger

Of winds in their fury,

Tempestuous voices,

Make ye no clamour,

Run ye less swiftly,

Sith sleepeth the child here

Still ye your branches.

He the divine child

Is here a-wearied

Of weeping the earth-pain,

Here for his rest would he

Cease from his mourning

Only a little while,

Sith sleepeth this child here

Stay ye the branches.

Cold be the fierce winds,

Treacherous round him.

Ye see that I have not

Wherewith to guard him,

$\mathrm{O}$ angels, divine ones

That pass us a-flying,

Sith sleepeth my child here

Stay ye the branches. [1996:24-25]

Pound employs in this translation a number of devices and techniques that would become more famously associated with his «The Seafarer» (1911): archaic and faux-archaic diction, a mixture of Latinate and Anglo-Saxon formulations («sith sleepeth,» «earth-pain,» «ye,» "Wherewith»), and a loose meter that turns on staggered syllable counts. This deviation from what he characterized later as Lope de Vega's colloquialism in verse was a continuation of Pound's own developing style. He even drafted in 1907 an incomplete and unpublished baroque-style play called 
Quevedo, after Lope de Vega's rival Francisco de Quevedo. But while he will discuss Lope de Vega in Spirit of Romance, his rejection of both Rennert's mode of academic investigation and Lope de Vega's aesthetics will become the more visible parts of his ensuing scholarship and poetics.

\section{The End of Philology and a Comparative Approach to Lope de Vega}

In these Spanish essays and translations, Pound frames the larger intellectual issues that he was beginning to engage. In fact, one of the other essays for Book News Monthly, «Raphaelite Latin», launched his assault on the "Germanic ideal of scholarship» (philology) and its excessive and misguided fixation on what the "author wore and ate» [1906:301]. Unlike Rennert, Pound could not stand for "perversion of that primitive religion» of "hero-worship» that philology had made of the study of literature (The Spirit of Romance, p. 7). Likewise, he could not sustain an interest in technical questions of historical syntax or in theater alone; Rennert studied both Castilian Spanish and Italian, but Pound was more intrigued by the reciprocal transformations and tensions among Spanish, Provençal, Italian, and more. After a brief, disastrous stint teaching Spanish and French at Wabash College in Indiana in 1908, it was clear that he would not follow Rennert into academia. Instead, Pound recycled material from Rennert's seminars into a series of lectures that he presented at Regent Street Polytechnic in London in 1908-09. Those lectures would combine with his formation in US universities and his research in Spain to become his book The Spirit of Romance: An Attempt to Define Somewhat the Charm of the Pre-Renaissance Literature of Latin Europe (1910). ${ }^{4}$ This extraordinary, at times audacious text, which Richard Sieburth calls Pound's "first sustained archaeological excavation of the Tradition of the New», is something of a summa of Pound's intellectual development by 1910, when he turned 25 [2005:viii]. His Spanish studies factor centrally into Spirit's argument, its comparative method, and its translational style, all right on the heels of Rennert's The Spanish Stage in the Time of Lope de Vega (1909).

4. Hereafter abbreviated in text as SR. Pound offered the book to Penn in 1920 in hopes of earning his Ph.D., but the university declined. He tried again with a paleographic edition of Guido Cavalcanti: Rime (1932) but was denied again. 
Pound declares in the first words of his preface that «this book is not a philological work» (SR, p. 7). He writes that he has «floundered somewhat ineffectually through the slough of philology" in his academic life, and he has acquired a particular hatred of the Germanic model of the discipline, which he saw as having no sense of comparative judgment and as being confined to «morphology, epigraphy, and privatleben» (SR, p. 7). He later added bluntly that the «"university system" of Germany is evil» [1917:245]. Pound already had rebelled against the German philological model in his coursework at Penn; he hated, too, what E.M. Butler called in the title of a 1935 book The Tyranny of Greece over Germany. This tyranny remained powerful even as philology, which had its golden age from roughly 1777-1872, was beginning its decline after Nietzsche renounced it in his Birth of Tragedy (1872). Against philological paradigms, Spirit, as a source-book and textbook —over half of it composed of Pound's translations - relies on Pound's claim that "poetry is a sort of inspired mathematics, which gives us equations, not for abstract figures, triangles, spheres, and the like, but equations for the human emotions» that need not (like his study) cohere, only escape from the confines of rhetoric ( $S R$, p. 14). At once burnishing his credentials earned in conservative academic environments and radically transforming the practices he mastered there, Pound lays the groundwork for an understanding of Spain's literary past and its relevance to the twentieth century, when Spain, he believed, had cordoned itself off from its formerly enriching international circuits.

After praising the Poema del Cid and countering Gaston Paris's nationalistic readings of medieval ballads, Pound dedicates a chapter of Spirit to Lope de Vega, despite the fact that he was working in more difficult conditions than his English peers: «Lope certainly found his stage in a much more rudimentary condition than Shakespeare found the stage of England. Whatever be the intrinsic merit of Lope's work, this much is certain; he gave Spain her dramatic literature, and from Spain Europe derived her modern literature» (SR, p. 181). Pound's comparative focus on Lope de Vega not only differs from Rennert's singular approach, but also keeps the playwright's works in conversation with the English and European texts that Pound praised. Shakespeare, as several points in the chapter, provides the most common comparative contrast. Pound agrees that Lope de Vega admirably created a «national theatre» in Madrid, and he notes that «Lope is bound to the Middle Ages much more closely than are the Elizabethans», because of his "religious plays», 
which Pound condemns as "scarcely belong[ing] to world literature» (SR, p. 182). His best plays, however, are "prophetic of the future stage», and they are «as fresh and playable today as they were in $1600 »(S R$, p. 197).

Pound summarizes —often unenthusiastically — several of Lope de Vega's plays, including El Nuevo Mundo descubierto por Cristobal Colón, Los novios de Hornachuelos, and El desprecio agradecido, and he translates several sections of dialogue from each of them. But he spends his greatest critical energy focusing on Las almenas de Toro, which "has the additional interest for us in that Ruy Diaz appears in it, the time treated being slightly earlier than that shown in the Poema del Cid» (SR, p. 191). He begins by describing the scene before the closed walls of Toro that Pound will recycle throughout his poetry, where the Cid, as in the Poema, appears before a "well locked [...] gate.» Pound then translates King Sancho's lines as he sees his sister Elvira (whom he does not recognize):

\section{The King:}

On the battlements of Toro

There passed a damozel, or

To speak more truly

'Twas the sun's self passed us,

Fair the form and light the passing.

For her whom I saw on the wall that subtlety wherewith astronomy painteth aloft her divers sights upon the azure mantle of the sky, hath made me such that I believe many imagined things should be true. (SR, p. 192)

This scene was crucial to Pound, who translates it again with a blend of archaic and modern Anglo-Saxon and Latinate phrasing, because it incorporated several motifs and themes: closed gates or walls, misrecognition, incest, and the threat of violence. Furthermore, it brings out the key difference between Lope de Vega and Shakespeare that Pound elsewhere describes: «Shakespeare's convention is that of ennobled diction», whereas Lope de Vega's «speech is characteristic of his people, but is more impressive than ordinary speech». Lope de Vega relies more than Shakespeare on "rhymes and assonance», and when he "becomes ornate, irony is not far distant», because the "nature of the Spanish language permits rhyme and assonance, without such strain or cramping as these devices would generate in 
English». For Pound, Lope de Vega's «speed in dialogue», short lines, and «swiftness» must be captured by a translation that does not slow these traits and, at the same time, reproduces the «blemishes» of «carelessness» that mark the Spaniard's plays (SR, p. 204).

\section{Re-Reading Literary History: The «UR-Cantos»}

But did Lope de Vega inaugurate a "great age» of letters in Spain — which matters the most for Pound - and where did he fit in the comparative spirit of post-medieval Europe? «A great age of literature is perhaps always a great age of translations; or follows it», he claimed, in a point he would make many times across his career [1968c:232]. Pound held that «neither is there any point in studying the "History of English Literature" as taught. Curiously enough, the histories of Spanish and Italian literature always take count of translators», whereas English literary histories "slide over» it out of fear of being labeled unoriginal [1968b:34]. Spain's literary vitality, then, came when it was a haven for translators. But in Spirit, Pound is unsure if Spain's Golden Age had reached its maximum potential. He noted that Lope de Vega was a "prince of letters» and that a "great age of letters» in Spain was possible with Cervantes and Calderón, but even while praising the latter two figures, he hesitates and never concludes that this «great age» came to fruition (SR, p. 210). As he moved on from Spirit, his theories of translation in comparative literary histories come to dominate his thought. What he was working out implicitly in Spirit of Romance became more explicit in the following year, when he published «The Seafarer» and began articulating a praxis-based conception of translation that allow him to rewrite and re-envision the Poema once again in his "Ur-Cantos», now as a part of an even wider scope of global literary history in which he would reconfigure and extend his readings of Spain's past.

In Spirit Pound mostly retained an exegetical or pedagogical style of translation, but he deviated from scholarly and translational norms that he had cited and analyzed by infusing with liberal creativity at important moments. He still held on, at times, to a linguistic essentialism ("the cadence and rhyme of [Lope de Vega's] Spanish gives it a certain suavity which I cannot reproduce», $S R$, p. 201). But he also introduces in Spirit the idea that «substitutions» in translation must be 
liberal: writing of Arnaut Daniel's difficult language, he notes that «very often a Romance or Latin word stands between two English words, or includes them» (SR, p. 26). He half-praises Shelley for his «endeavor to translate a part of Dante's message into the more northern tongue», and he faults English translators of the iconic Portuguese poet Luís de Camões:

The beauty of Camoens will never be represented in English until his translators learn to resist translating every Portuguese word by an English word derivative from the same Latin root. The translation of Camoens into words of Saxon origin would demand a care of diction equal to that of the author, and would retain the vigor of the original. A translation filled with Latinisms looks like a cheap imitation of Milton. (SR, pp. 156, 215)

He even calls one of his own translations of Lope de Vega «appalling in its crudity» ( $S R$, p. 201). In other words, the method of foreignization (to use Lawrence Venuti's term) that Pound was devising requires blending the source and target languages' traits, as he did in his translations of the Poema for Spirit, and then allowing them to estrange once another reciprocally. Furthermore, his claim in Spirit that "all ages are contemporaneous» makes sense only in that translation creates this transtemporality, and it would do so in the collage of the poetic sequence that would consume the rest of Pound's life, The Cantos (SR, p. 8).

Pound thus remarked to William Carlos Williams that «sometimes I use rules of Spanish, Anglo-Saxon and Greek metric that are not common in the English of Milton's or Miss Austen's day» [1971:8]. And so, in an almost seamless transition, when Pound began in earnest in 1915 «really L O N G, endless, leviathanic» poem, he realized that it would only come into being through a constant process of translation, retranslation and revision [1971:104]. After a number of plans, revisions, false starts, missteps, hesitations, and confrontations with Browning, he published the first three cantos, known collectively as the «Ur-Cantos», individually across three months of the magazine Poetry in 1917. ${ }^{5}$ In them, Pound turns the montage of fragments, or «super-position», into a new mode of translation that traverses Greece,

5. The genetic and compositional history of these cantos is very complex. Pound began revisions on them before they even appeared in Poetry, then printed new versions of them in the American edition of Lustra, in the magazine Future, and in parts of several other essays. See Bush [1976]. 
China, Egypt, Italy, «middle Indiana», Catullus, noh theater, the occultist John Heydon, and a bewildering array of temporalities («you mix your eras», he says approvingly to Browning). Pound thus «stuff[s]» into his poetic «rag-bag» a mixture of translations, paraphrases, revisions, misdirections, and reinventions of the Poema. In the second of the «Ur-Cantos», we find both Lope de Vega and the Cid, once again next to the troubadours Joios [or Joyos de Tolosa] and Arnaut Daniel, but also next to much more, including Pound himself, in an extended passage:

When I was there,

La Noche de San Juan, a score of players

Were walking about the streets in masquerade,

With pike-staves and paper helmets, and the booths,

Were scattered align, the rag ends of the fair.

False arms! True arms? You think a tale of lances...

A flood of people storming about Spain!

My cid rode up to Burgos,

Up to the studded gate between two towers,

Beat with his lance butt.

A girl child of nine,

Comes to a little shrine-like platform in the wall,

Lisps out the words, a-whisper, the King's writ:

«Let no man speak to Diaz or give him help or food

On pain of death, his eyes torn out,

His heart upon a pike, his goods sequestered».

He from Bivar, cleaned out,

From empty perches of dispersed hawks,

From empty presses,

Came riding with his company up the great hill-

«Afe Minaya!»

to Burgos in the spring,

And thence to fighting, the down-throw of Moors,

And to Valencia rode he, by the beard!

Muy velida.

Of onrush of lances,

Of splintered staves, riven and broken casques,

Dismantled castles, of painted shields split up,

Blazons hacked off, piled men and bloody rivers;

Then "sombre light upon reflecting armor» 
And portents in the wind, when De las Nieblas

Set out to sea-fight,

"Y dar neuva [sic] lumbre las armas y hierros».

Full many a fathomed sea-change in the eyes

That sought him with the salt sea victories.

Another gate?

And Kumasaka's ghost come back to tell

The honor of the youth who'd slain him.

Another gate.

The kernelled walls of Toro; las almenas.

Afield, a king come in an unjust cause.

Atween the chinks aloft flashes the armored figure,

Muy linda, a woman, Helen, a star,

Lights the king's features...

«No use, my liege-

She is your highness' sister,» breaks in Ancures;

"Mal fuego s'enciende!»

Such are the gestes of war "told over and over.»

And Ignez?

Was a queen's tire-woman,

Court sinecure, the court of Portugal;

And the young prince loved her-Pedro,

Later called the cruel. And other courtiers were jealous.

Two of them stabbed her with the king's connivance,

And he, the prince, kept quiet a space of years-

Uncommon the quiet.

And he came to reign, and had his will upon the dagger-players,

And held his court, a wedding ceremonial-

He and her dug-up corpse in cerements

Crowned with the crown and splendor of Portugal.

A quiet evening and decorous procession;

Who winked at murder kisses the dead hand,

Does leal homage,

"Que depois de ser morta for Rainha.»

Dig up Camoens, hear out his resonant bombast:

«That among the flowers,

What have we now of her, his «linda Ignez»? [1917b:184-187] 
Pound begins with his own time in Spain ("When I was there») and then blends La noche de San Juan (Lope de Vega's play) with St. John's Eve, a festive holiday that occurred while he was there. He then sets the scene as a chaos of personae and impersonation: at the "masquerade», he sees Spaniards in "Pike-staves and paper helmets», with the former (also known as "pikestaffs") bringing together the two key words of the poetics of this passage: "pike" and "stave" (a "stave" is also a poetic unit, similar to a stanza, that Pound had mentioned in his previous poetry, and that he is now "splinter[ing]» both syntactically and thematically). He repeats certain language from his previous version of the Poema that he offered in Spirit of Romance («lances», and "riven», which now rhymes partially with "rivers») and rephrases and alters a great deal of that text ("An oval shield there riven lies" becomes "painted shields split up»). In what becomes a self-referential scene, the violence depicted expresses the fragmenting, distorting violence of translation and poeticization that Pound enacts, and vice versa. Pound then moves from the Cid at the gates of Burgos to Juan de Mena and to Shakespeare's The Tempest, before he asks, «Another gate?».

The first new "gate» is from noh theater; the next is from Lope de Vega. Pound explained in a letter to his father, "Elvira on wall or Toro (subject-rhyme with Helen on Wall)» [1971:210] (Elvira, of course, is a character in both Lope de Vega's Las almenas de Toro and the Poema del Cid). The «subject-rhyme» in this series of "gates» and sieges turns to «The kernelled walls of Toro; las almenas». Here, through such super-positions, Elvira is Helen, who also is the Galician noblewoman Inés de Castro ("Ignez de Castro» in the Cantos), a member of the Portuguese court of the early 1300s, the secret lover of Pedro I of Portugal, and the subject of Lope de Vega's lost play Doña Inés de Castro. Sancho speaks Italian —not Spanish—in Pound's translingual rendition of his cursing of Elvira: «May an ill flame be kindled in her!».

Pound moves more centrally, then, to Inés: the Portuguese king Alfonso IV, who disapproved of Inés and Pedro's relationship, had her murdered and dismembered. When Pedro ascended to the throne, however, he claimed that he had privately married her before her death, and thus he had her corpse exhumed and brought before the court, where he forced all of the nobles to kiss her hand and swear allegiance. This story forms part of Camões's Lusiads, which Pound had treated in Spirit, but had grown to see as even more faulty than he previously recognized. 
Camões was, in effect, trapped by his conception of time; «an epic cannot be written against the grain of its time», Pound wrote (SR, p. 216). Thus, Camões failed to represent Inés's story and «the splendid horrors of the Spanish past» because he wrote them as a "mirroring» rather than as "the simplest narration of the events themselves» (SR, pp. 219, 218). These aesthetic judgments determine Pound's treatment of these texts and figures that he will «dig up», as he writes of both Inés's corpse and Camões, in the Cantos. "Art that mirrors art is unsatisfactory", Pound wrote in his critique of baroque aesthetics, and history could only enter epic poetry through collage, not through narrative mimesis ( $S R$, p. 218). For Pound, Iberian literature in the Baroque era - an era that failed to maintain the translational, international, polysemic potential that the Poema and the late Romantic literatures of Europe had endowed to Spain - was finally a dismembered corpse that he could not draw upon vitally in his own poetry.

\section{The Death of Spanish Literature and Its Fragments in the Cantos}

If Pound began to seal his critiques of post-medieval Spanish literature's wrong turns in the "Ur-Cantos», he presented them even more audaciously in the following years; from here, we can understand why the intellectual project that had preoccupied him through to the first draft of his Cantos was now being pushed aside, with Spanish literature relegated to the margins. Already by 1916, Pound's growing distaste for Spanish literature as a whole was becoming apparent: he told Iris Barry that a course in "KOMPLEAT KULTURE» should include Catullus and the troubadours; skip the Elizabethans and their modern imitators; and from «Spanish, nothing. Italian, Leopardi splendid [...] but not essential as a tool. Spain has one good modern novelist, Galdos» [1971:91]. By 1920, when Pound corresponded with Miguel de Unamuno, his Spanish had grown nearly too rusty to be intelligible. (By the time of the Pisan Cantos, most of Pound's fragments and phrases in Spanish are ungrammatical and misspelled). Always seeking to publish in international forums, however, Pound contributed two essays to the Spanish periodical Hermes in 1921. One is a short survey of contemporary literary movements in England, highlighting Imagism, Eliot, Joyce, and Lewis. The other, much longer, is a caustic condemnation of Spanish literature that Pound wrote especially for the Spanish people, 
a condemnation not unlike his attacks on English literature that aimed to jolt public consciousness toward re-envisioning a more nourishing literary heritage.

Transferring his and Eliot's attacks on English literary history to Spain, Pound claims in «Some Notes on Francisco de Quevedo Villegas» that a rampant «Elizabethanism» is the "disease of Spanish literature» [1991:12]. But just as «the rhetoricians "ruined the Roman empire"», a love of «indirectness» overtook Spanish writing during the Baroque era, when «ornament of detail» became more important than subject matter, even in Calderón's plays [1991:12, 13]. What happened to Spanish literature? How did the country that, Pound claimed, gave the early troubadour Guillaume de Poitiers his song and inspired the prose of the French Renaissance decline so far? He argues that «the vitality of Spain runs in the Poema del Cid, the best, I think, of all chancons de geste, in Calisto y Melibea, in Rojas [The Tragicomedy of Calisto and Melibea by Fernando de Rojas], in the invention of Lope, in Cervantes». But to account for Spain's literary decline, on the whole, Pound asserts that one must look to political history. He notes that uhard shell democrats will doubtless consider the decline of the Spanish cortes, the foreign relations of Charles V, and the "Flemmings" to blame for the Spanish fading" [1991:13]. The reasons Pound cites were common explanations: the turn away from liberal reform in parliament (the cortes), the Counter-Reformation that Charles V pushed, or the costly and ill-advised Eighty Years' War. Spain becomes an exceptional case for Pound, one in which imperial power and literary greatness went hand in hand. Even when he compliments Lope de Vega, his dismissals of the playwright are in the background and will become more apparent in the Cantos. Furthermore, he adds that Lope de Vega's rival Quevedo was the last great Spanish writer until Galdós, then adds that Quevedo was not deserving of his reputation. (He will shift his opinion of Galdós, too).

Pound then asks rhetorically, «did [Spain's] literature cease to be of international importance chiefly because of her obstination in mediaeval philosophy and religiosity?» [1991:16]. This «obstination» corresponds to two historical movements that Pound blamed for Spain's lost greatness: one is the Reconquest, which purged Moorish thought and assimilated parts of it to an exclusively Catholic, Hispanic nation that would become the Spanish imperial state over the following centuries. This consolidation killed the transnational «spirit of romance» that Pound saw in the Poema; but even this «disease is not geographically Spanish» [1991:13]. «Other 
countries have recuperated» after closing off their borders to "the other world», and Spain had a chance to return to «the main European current» in the 1700s [1991:19]. But Spain's writers chose to narrow their national culture rather than to recover the «meandering» and varied network of «castles» that made the Europe he analyzed in Spirit so full of life [1991:19]. In other words, the Counter-Reformation and Inquisition cut off the circuits of translation and cultural import-export systems that fed the once powerful literary tradition in Spain. As he notes in Canto LII, «Once only in Burgos, once in Cortona [Tuscany] / was the song firm and well given / old buffers keeping the stiffness» [1996:258]. The Baroque —Spain's last influential era, he holds - had set the country on a course that caused a "great deal of Spanish poetry» to become full of "ornament», enslaved by imitation and unable to liberate itself from «time» as great literature does, as Pound noted in a 1929 postscript to Spirit (SR, p. 211). By the twentieth century, Spain was «not a civilized nation», but «damn'd nest of savages» that warranted the old European prejudice that Europe ended with the Pyrenees [1952:158].

By the time Pound published A Draft of XVI. Cantos (1925), the Baroque era and its use of «ornament» are almost fully dismissed; most of the lines on Inés de Castro are cut and Camões is only present faintly. He writes in Canto III:

And he came down from Bivar, Myo Cid,

With no hawks left there on their perches, And no clothes there in the presses,

And left his trunk with Raquel and Vidas,

That big box of sand, with the pawn-brokers,

To get pay for his menie,

Breaking his way to Valencia.

Ignez de Castro murdered, and a wall

Here stripped, here made to stand. [1996:11]

The Cid, in greatly truncated form, now stands next to an allusion that combines Inês and Elvira more fully. The scene has shifted to his deception of the Jewish moneylenders, and Lope de Vega is all but absent. Pound comes back to Lope de Vega in Canto XX, though this time, through voice of the Italian nobleman Niccolò d'Este, who witnesses an execution in medieval Italy which Pound transports to Lope de Vega: 
And they were there before the wall, Toro, las almenas, (Este, Nic Este speaking)

Under the battlement

(Epi purgo) peur de la hasle, And the King said «God what a woman!

My God what a woman» said the King telo rigido «Sister!» says Ancures «'s your sister!» Alf left that town to Elvira, and Sancho wanted It from her, Toro and Zamora, «Bloody spaniard!» [1996:91]

Lope de Vega's play now allows a transhistorical, cross-linguistic restaging of executions against walls, colliding no longer with the Cid before the walls of Burgos. Ancures's lines of warning to Sancho are now more emphatic, and Este himself seems to curse Sancho as a «Bloody spaniard!» in this juxtaposition of time and space. Elvira's separation from the line of Spanish literary history that Pound was drawing out earlier in his work continues when, in Canto XXX, the scene of Inés's murder that crossed Lope de Vega and Camões is cast amid allusions to Greek gods and scenes of the Borgias. Finally, in Canto LXXVIII, he writes,

To be gentildonna in a lost town in the mountains on a balcony with an iron railing with a servant behind her as it might be in a play by Lope de Vega. [1996:502]

By this point, Lope de Vega is no more than a vague of point of reference, much like Juana la Loca in the lines that follow. Pound scatters other allusions and references to Spain across the Cantos —Spain's declining empire and the Spanish Civil War are both briefly treated - but Lope de Vega and his literary compatriots could not make a literary world "cohere" for Pound in the way that Homer or late medieval Italy ultimately could. Pound's failed projects of the 1910s and what he saw as Spain's failed literary history — the promise and the missed opportunities embodied by Lope de Vega- would cross and draw on another only faintly as the poet jettisoned yet another mask of his youth in favor of the multiform disfigurements through which he would fashion his lasting iconic legacy. 


\section{BIBLIOGRAPHY}

Bush, Ronald, The Genesis of Ezra Pound's «Cantos», Princeton UP, Princeton, 1976.

Carpenter, Humphrey, A Serious Character: The Life of Ezra Pound, Houghton Mifflin, Boston, 1988.

Moody, A. David, Ezra Pound, Poet: A Portrait of the Man and His Work. Vol. 1: The Young Genius, Oxford UP, New York, 2007.

Pound, Ezra, «Burgos: A Dream City of Old Castile», Book News Monthly, XXV 2 (October 1906a), pp. 91-95.

Pound, Ezra, «Raphaelite Latin», Book News Monthly, XXV 1 (September 1906b), pp. 31-33.

Pound, Ezra, «Mr. James Joyce and the Modern Stage», The Drama, VI 21 (February 1916), pp. 122-132.

Pound, Ezra, "Provincialism the Enemy: I», New Age, XXI 11 (12 July 1917), pp. 245-246.

Pound, Ezra, «Three Cantos: II», Poetry, X 4 (July 1917b), pp. 180-188.

Pound, Ezra, Guide to Kulchur, New Directions, New York, 1952.

Pound, Ezra, EP to LU: Nine Letters Written to Louis Untermeyer by Ezra Pound, ed. J.A. Robbins, Indiana UP, Bloomington, 1963.

Pound, Ezra, Cantos, New York: New Directions, 1968a.

Pound, Ezra, «How to Read», in Literary Essays of Ezra Pound, ed. T.S. Eliot, New Directions, New York, 1968b, pp. 15-40.

Pound, Ezra, «Notes on Elizabethan Classicists», in Literary Essays of Ezra Pound, ed. T.S. Eliot, New Directions, New York, 1968c, pp. 227-248.

Pound, Ezra, The Spirit of Romance: An Attempt to Define Somewhat the Charm of the Pre-Renaissance Literature of Latin Europe, New Directions, New York, 1968d.

Pound, Ezra, Selected Letters of Ezra Pound, 1907-1941, ed. D.D. Paige, New Directions, New York, 1971.

Pound, Ezra, «Some Notes on Francisco de Quevedo Villegas», in Ezra Pound’s Poetry and Prose: Contributions to Periodicals, pref. and arranged L. Baechler, A.W. Litz, and J. Longenbach, Garland, New York, 1991, vol. 11, pp. 16-21.

Pound, Ezra, «Song of the Virgin Mother», in Early Poems, Dover, Mineola, New York, 1996.

Pound, Ezra, ABC of Reading, intro. M. Dirda, New Directions, New York, 2010. 
Pound, Ezra, Ezra Pound to His Parents, eds. M. de Rachewiltz, A.D. Moody, and J. Moody, Oxford University Press, New York, 2010.

Sieburth, Richard, «Introduction to Ezra Pound», in The Spirit of Romance, New Directions, New York, 2005, pp. vii-xii. 